\title{
Pollution: The Pathogenic and Xenobiotic Exposome of Humans and the Need for Technological Change
}

\section{Alejandro de las Heras , Marina Islas-Espinoza , Araceli Amaya Chávez}

To cite this entry: Alejandro de las Heras, Marina Islas-Espinoza, Araceli Amaya Chávez .

Pollution: The Pathogenic and Xenobiotic Exposome of Humans and the Need for

Technological Change. In Encyclopedia of Environmental Management. Taylor and Francis: New York, Published online: 28 Jan 2016; 1-10.

To link to this chapter: http://dx.doi.org/10.1081/E-EEM-120052926

Published online: 28 Jan 2016

Submit your article to this journal $₫$

View related articles 


\title{
Pollution: The Pathogenic and Xenobiotic Exposome of Humans and the Need for Technological Change
}

\author{
Alejandro de las Heras \\ Water Appropriate Technologies, Toluca, Mexico

\begin{abstract}
Marina Islas-Espinoza
Engineering Department, Inter-American Centre for Water Resources, Mexico State University, Toluca, Mexico
\end{abstract}

\author{
Araceli Amaya Chávez \\ Chemistry Department, Pharmacy Group, Mexico State University, Toluca, Mexico
}

\begin{abstract}
The available dominant water, energy, and food (WEF) technologies are responsible for the expansion of pathogenic exposure via climate change and land change at the global scale: there are 1415 known pathogens and 175 are emerging ones, described in the last 40 years. Expansion of xenobiotic exposure is occurring due to the production of 250,000 compounds and an average of 4400 new ones each year. A variety of pathogenic and WEF xenobiotic agents affecting the human species is charted here. The basal pathogenic human exposome (or lifelong exposure) and the anthropogenic exposome expansion are related to the human bodily systems, to highlight concurrent damages. Foremost among interactions are cancers, which most often result from several mutations after exposure to pathogens or xenobiotics. Of particular interest are emerging pathogens with different bodily effects, and pathogen-xenobiotic interactions, which affect the reproductive/ endocrine/developmental systems: these systems are under anthropogenic evolutionary pressure. WEF technologies form an intertwined nexus such that phaseout of a few dominant but obsolete technologies can effect crucial changes in current human health trends. Prevention is of essence, which means that already available, sustainable, technologies have to be implemented.
\end{abstract}

\section{INTRODUCTION}

In the last 4-8 million years of human evolution, colonization of different environments, volcanic events, and climate change have brought about different exposures to disease: in forests, pathogens (microbiological and parasitic agents) benefited from high temperature and moisture. In savannahs, dust became important. ${ }^{[1]}$ About 400,000 years ago, fire technology was used and foreboded the anthropogenic exposome; cooked meat was more digestible, contributing to evolving a shorter intestine requiring less energy, which allowed for the energy consumption of a larger brain. ${ }^{[2]}$ For the last 10,000 years, husbandry has intensified our exposure to zoonoses. ${ }^{[1]}$

Then, after 1840 , sewerage and water sanitation were implemented, considered by the medical profession the key drivers of our current extended life-expectancy. ${ }^{[3]}$ However, climate change and food production technologies are prime movers of deleterious changes of human health. ${ }^{[4,5]}$

Technological changes are required in view of the crisis of public health responses to (re) emerging, ${ }^{[6]}$ neglected diseases, and resistance to known treatments.

\section{Exposome and Cancer}

The exposome is the lifetime set of exposures affecting an organism since before conception (see Wild et al. ${ }^{[7]}$ ). There are 1415 pathogens known and 175 species are emerging, described in the last four decades. ${ }^{[8]}$ It is in response to pathogens that our immune system has evolved. Our exposome is expanding due to increased xenobiotic emissions and, surprisingly, pathogen emergences. Cancer morbidity is on the rise, linked to both pathogens and xenobiotics. Cancers are mostly related to our environment and behavior and so are essentially preventable. ${ }^{[9,10]}$

\section{HOW DOES OUR EXPOSOME GROW?}

\section{Pathogens}

Human inroads into wild habitats increase our contact with pathogens, and so does pathogen migration following regional changes in temperature and moisture (Fig. 1). In a majority of emerging diseases, bloodsucking mosquitoes, ticks, or bugs transmit pathogens 


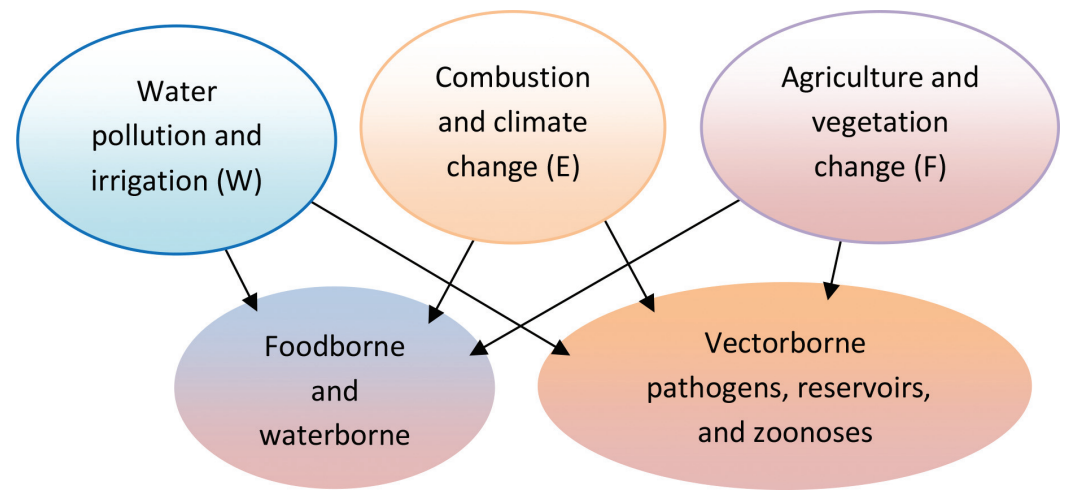

Fig. 1 The WEF nexus of pathogenic dispersal and proliferation. from one mammal or bird host to another. Livestock and household animals become infected by one or several pathogens (coinfection) and increase the number of host species.

Pigs are often mentioned as a host where mixtures of pathogens occur, and multi-resistance to antibiotics develops. Pigs may act as an amplifying host in whose body enough pathogens grow for vectors to become infected. Triple reassortment influenza viruses have pig, avian, and human genes and are now dominant in the US pig population. ${ }^{[11]}$ Humans may transmit influenza viruses to pigs who then act as mixing vessels for new reassortant influenza viruses with augmented pathogenicity and lethality in humans. ${ }^{[12]}$

This is aggravated by a revolution in husbandry based on antibiotics, which has allowed for very large and very dense livestock concentrations, conducive to propagation of pathogens.

Storage of staple grains, especially under warm and moist conditions, is a problem on the rise due to fungal aflatoxins, a well-known cause of cancer. This problem is worsened by agricultural overproduction.

Food is finally involved in the fecal-oral route of infection; the use of water to transport feces contaminates water bodies used for irrigation of fresh greens. The increase in nutrient load in water helps pathogen proliferation, especially under warmer conditions, affecting drinking water (Fig. 1).

Despite apparently more dramatic effects of pathogens in the tropics, emergent diseases are more often observed in northern latitudes, ${ }^{[8]}$ more densely populated and connected by transportation.

\section{Xenobiotics}

Chemicals produced worldwide were an estimated 60,000 in 1970, 100,000 in 1980, and 250,000 in $2010,{ }^{[13,14]}$ an increase of 4400 new compounds each year. Some are very hazardous and their release to the environment is subject to compulsory declaration; the latest edition of US Toxics Release Inventory comprises 734 industrially generated xenobiotics, 263 of which have known effects on humans.
One hundred are used or produced by food, 37 by energy, and 10 by water technologies. ${ }^{[15,16]}$

More generally, WEF-released xenobiotics belong to a dozen pollutant classes. Metal(loid)s stand out as used and emitted by all three WEF sectors. They are used as coagulants in water treatments, in fuels and battery electrodes, and as food additives. Metal(loids) are also present in wastewater sludge soil amenders used in agriculture, irrigation water containing industrial wastewater, and fossil fuel emissions.

Because fossil fuels pervade power generation, agricultural machinery use, food transport, and (waste-) water pumping and treatment, non-methane volatile organic compounds (NMVOCs) are emitted by all three WEF sectors. NMVOCs come from fuel tanks and combustion. Methyl tert-butyl ether (MTBE) and benzene, toluene, ethylbenzene, and xylenes (BTEX) are fossil fuel additives. Diesel exhaust and air pollution contain 3-nitrobenzanthrone (3-NBA).

Two other classes are persistent organic pollutants; they are chemically stable and so accumulate in the food chain and in human fatty tissues: polycyclic aromatic hydrocarbons (PAHs) come from petroleum, tars, combustion, fracking fluids used to extract natural gas, and are released by food preparation in toasted and grilled foods. Polychlorinated biphenyls (PCBs) were banned around 1980 in developed countries but continue to be released from polluted environments and confinement areas. Energy technologies have used PCBs for transformers and heat transfer equipment.

Pesticides are mixtures of several intentionally toxic compounds; they overlap with other classes like metalloids, PCBs, and hormone disruptors.

Endocrine disruptors include hormones not synthesized by the body, hormone agonists that reinforce hormone effects, and antagonists that reduce hormone effects. Hormones are directly injected to livestock. PCBs and pesticides are endocrine disruptors.

Nitrate is released by agricultural inorganic fertilizers and manure into water and groundwater. Incomplete wastewater treatments and ill-contained sewage also release nitrate. Xenobiotic nitrites and nitrates lead to excess 
consumption of otherwise beneficial nitrates and nitrites from vegetables. Nitrate and nitrite are used in food smoking or as meat and vegetable preservatives. N-nitroso compounds come from beer and processed meat and via the chemistry of nitrite and nitrate in our body. Sulfites are used as food anti-browning and preservative agents. Acrolein and acrylamide are released by cooking at high temperatures.

Radionuclides emitted by nuclear power plants, coal mining, and combustion, as well as phosphate fertilizers, are high-energy particles.

Chlorine, ozone, and UV have deleterious effects of their own and through their disinfection by-products (DBPs). Acrylamide, used as coagulant in potable and wastewater, is released in sludge to the environment.

\section{MULTIPLE DAMAGES}

WEF-related pathogens and xenobiotics often cause multiple damages in the human body (Fig. 2A and 2B). WEF xenobiotic classes cause more cancer damages than cancerinvolved pathogens (4.6 and 3.3 damages on average, respectively). WEF xenobiotic classes also promote or cause more non-cancer damages (14 and 3.8 damages on average, respectively). This more varied xenobiotic exposome hinges on a much larger number of interacting xenobiotic compounds.

Also relevant for prevention purposes are three pathogens high on both cancer and non-cancer counts: HIV-1, herpes virus 4 (Epstein-Barr virus), and herpes virus 8 . High on the cancer count are human papilloma viruses, Opisthorchis viverrini and Clonorchis sinensis bacteria, PCBs, and metal(loid)s. There are no xenobiotic classes high on the non-cancer score only.

Considering 17 systems in the human body, as well as cancer and non-cancer damages, there are 34 possible targets for the 27 pathogens listed here (Fig. 2A). HIV-1 stands out with 14 targets and herpes viruses 4,5 , and 8 with 9-12 targets each. These four viruses account for $29 \%$ of all pathogenic targets comprised here.

Similarly, four xenobiotic classes account for $50 \%$ of all xenobiotic targets (PCBs; metal(loid)s; pesticides; acrolein, acrylamide, and polyacrylamide). Overall, 11 xenobiotic classes (Fig. 2B) target the respiratory, reproductive, dermal, renal, and immune system the most, and these systems account for $50 \%$ of the xenobiotic targets.



Fig. 2A Multiple pathogenic damages from known pathogens implicated in infections, cancers, and other chronic damages. Sources: Diseases Database ${ }^{[17]}$ and WHO. ${ }^{[18]}$ 


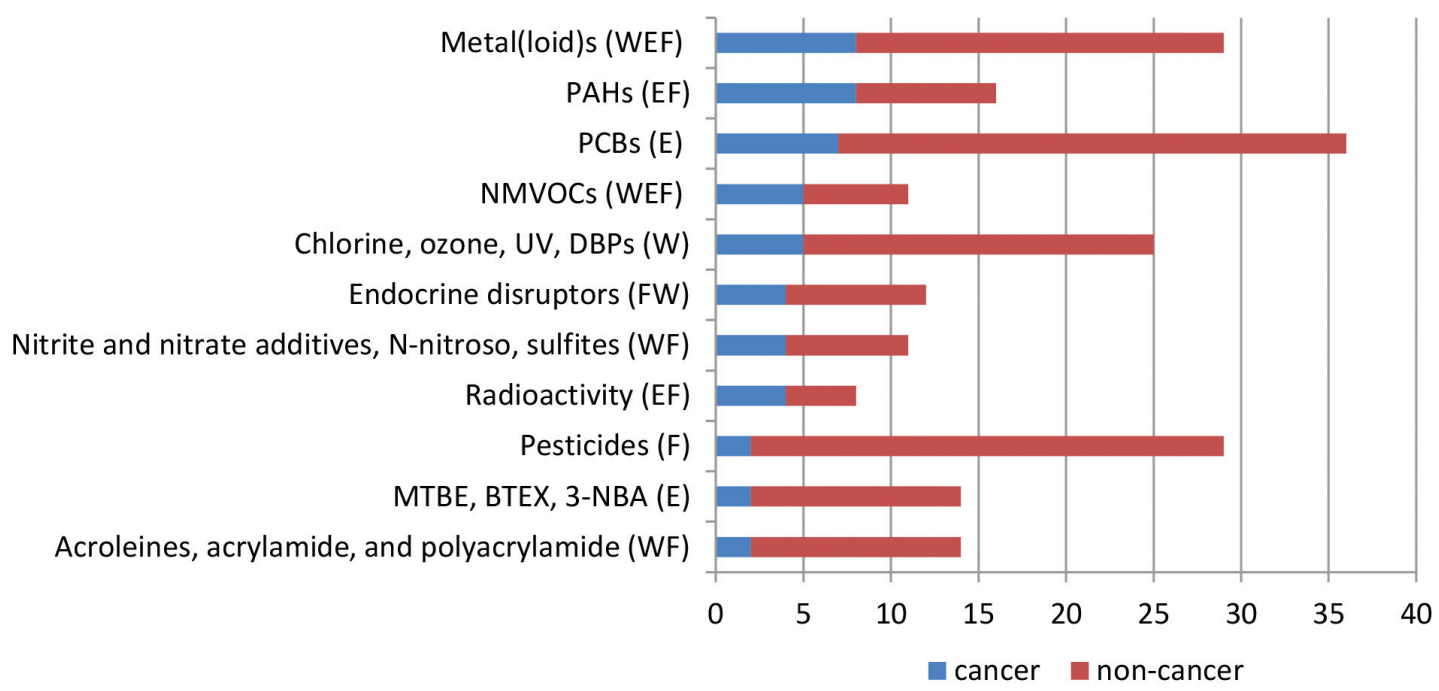

Fig. 2B Multiple xenobiotic damages. Main xenobiotic classes used, produced, or released as by-products by WEF technologies. Data sources for this figure and simplified mechanisms of action are as follows. Note that within each class, specific compounds have different effects. Also, nitrate and polyacrylamide are not directly toxic but their metabolic products and manufacturing inputs are, respectively. Metal(loid)s ${ }^{[19,20]}$ bind to important biomolecules altering their functions. PAHs ${ }^{[20,21]}$ and NMVOCs ${ }^{[20,22,23]}$ are genotoxic, embryotoxic, mutagenic and carcinogenic. $\mathrm{PCBs}^{[24,25]}$ are immunotoxic and affect interactions with pathogens; they interact with hormone-responsive tissues, can modify toxicity of other chemicals, durably attach to DNA strands and are linked to carcinogenesis. Chlorine, ozone, UV, $\mathrm{DBPs}^{[26-33]}$ interact with other xenobiotics, lead to cell destruction, bind to biomolecules and are carcinogenic and genotoxic. Endocrine disruptors $^{[33-37]}$ have the capacity to interfere with tissue development, function and susceptibility to diseases through life. Nitrite and nitrate react in the body to form carcinogenic nitrosamines and N-nitroso compounds. Sulfite preservatives are immunotoxic. ${ }^{\text {[3- }}{ }^{42]}$ Radioactivity $^{[43-46]}$ is teratogenic (affects early development) and ultimately affects DNA strands. Pesticides ${ }^{[20,47,48]}$ interact with biomolecules, are neurotoxic, immunotoxic, teratogenic, alter endocrine functions, interfere with intercellular communication, participate in heritable genetic diseases and are carcinogens and co-carcinogens. MTBE, BTEX, and 3-NBA ${ }^{[49,50]}$ are neurotoxic, mutagenic, genotoxic and carcinogenic. Acrolein and acrylamide ${ }^{[20,51-53]}$ are carcinogenic and genotoxic.

Xenobiotics target all systems, although the ear seems less affected. Non-targeted systems by pathogens analyzed here seem to be the endocrine, developmental, and ear systems.

\section{Endocrine, Reproductive, and Developmental Ailments}

The well-being of future generations is jeopardized by the exposure of endocrine and reproductive systems before conception. The latest literature highlights the embryotoxicity, genotoxicity, mutagenicity, and carcinogenicity of PAHs and NMVOCs as well as the link between NMVOCs and diabetes. Metal(loid)s are carcinogenic and cause testicular atrophy or infertility. Pesticides are implicated in reproductive and heritable genetic damages as well as hormone-related thyroid cancer. Pesticides are teratogens, and in human milk hormone disruptors are linked to testicular atrophy and low sperm counts; DDT in particular has estrogenic actions linked to breast cancer. Hormone disruption by persistent organic pollutants like dioxins and PCBs is involved in breast cancers. The increased consumption of animalderived food may promote hormone-dependent breast, ovarian, corpus uteri, and prostate cancers. ${ }^{[20,35,36,44,54-58]}$ This is due to the estrogen receptor and more generally the involvement of the endocrine system in proliferation, one necessary stage of cancer development.

Reproductive-endocrine-developmental synergies could be related to the decline in male fecundity, declining sperm quality, genital-urinary malformations, and testicular cancer. The origin of such phenomena seems to be in utero testicular or ovarian dysgenesis syndromes. Fecundity has also been correlated with life expectancy in a study on more than 43,000 men. $^{[59]}$

Pesticides and PCBs are xenobiotics with neurological and reproductive/endocrine/developmental deleterious effects. Four viruses (herpes viruses 2, 4, and 8 and HIV1) are linked to both nervous and reproductive systems.

\section{Interactions}

A pathogen-pathogen interaction augments virulence: the presence of amoeba improves the ability of Mycobacterium avium to cross the human intestine, replicate, and find shelter within amoeba against antimicrobials. Similarly, Legionella pneumophila adapts to amoeba and human immune system cells, which resemble amoeboid cells. Fungal pathogens also interact with bacteria and viruses. Successful virulence traits are then inherited, along with assortment traits that combine genes of several species. ${ }^{[60]}$ 


\section{BOX 1. CONCURRENCE OF PATHOGENS AND XENOBIOTICS}

A larger number of interacting pathogens worsen health outcomes. ${ }^{[60,65]}$ This is also the case when pathogens and xenobiotics target the same organs. One such situation is the interaction conducive to malignant lesions, between Epstein-Barr virus that infects $90 \%$ of the global adult population and the pervasive and persistent PCBs. ${ }^{[6]}$ Hepatitis B virus has several xenobiotic co-carcinogens such as aflatoxins and oral contraceptives. ${ }^{[67]}$

Similarly, autism is linked to herpes virus 5; measles or rubella during gestation or puerperium to pesticides, diesel exhaust, metals, or PCBs. Overuse of medical drugs is also implicated: antibiotics, vaccines, and multivitamins in early infancy. ${ }^{[68-72]}$

Among xenobiotic-xenobiotic interactions, the following stand out. Hormones administered to cows augment milk production, which upon ingestion can interact with human estrogens and nutrients in the evolution of several cancers. ${ }^{[35,61,62]}$ Childhood cancer and the rising trend of undescended testes in boys have consistently been linked to parental exposure to pesticides prior to childbirth, and to human milk containing several, possibly interacting, pesticides. ${ }^{[47,63]}$ Low levels of pesticides can be found in much of the human population, and exposure continues to grow. ${ }^{[64]}$

Pathogen-xenobiotic interactions at the organ or system level are particularly relevant to cancers which are now considered outcomes of successive induced alterations (Box 1).

\section{TECHNOLOGICAL IMPLICATIONS}

Pathogen emergence and xenobiotic emissions can be ascribed to current WEF technologies (Figs. 1 and 2B). Water, energy, and food alternative technologies are available, which can lessen or revert, if combined, the expansion of the human exposome.

\section{Water Technologies}

Current water technologies are beset by sewerage systems that involve high pumping energy costs, worsened by pervasive water leaks. Sewage is increasingly seen as a source of mixtures of pathogens that exchange mobile genetic elements that enable antibiotic multiresistance ${ }^{[73]}$ Mixtures of pathogens and xenobiotics are hard to remediate.

Similar issues affect drinking water networks. In addition, awareness of waterborne pathogen outbreaks and DBPs is mounting in developed countries, moving some countries to phase-out chlorine. In arid and semiarid regions, water scarcity leads to using water of poor biological quality, often shared with domestic animals. Issues in systems prevalent in developed countries preclude their use in most tropical settings.

Appropriate technologies are alternatives based on the natural processes that limit pathogen proliferation: UV radiation from the sun, such as used in solar disinfection (Sodis bottles); solar distillation for desalination and disinfection; oxygenation in ponds; slow filters that mimic the purifying action of soil layers. ${ }^{[74]}$ Finally, a running boil is a foolproof method; it is used in Canada and the United States during biological emergencies.

As an alternative to sewerage, the World Health Organization recommends recycling wastewater, greywater (domestic water not mixed with feces), feces, and urine to enhance soil fertility. ${ }^{[75]}$ Of particular importance is aseptic urine that is provided by healthy kidneys, and dry toilets to avoid flushing feces with drinking water. Aerobic compost of food waste and excreta can rise to $80^{\circ} \mathrm{C}$, which inactivates most pathogens. To avoid pathogenic and xenobiotic water pollution, livestock must be separated from potable water sources, while hospital wastewater must be treated in situ.

Appropriate technologies allow for autonomy: they are simple, inexpensive, and adaptable to local materials and skills. Large facilities require complex computerized monitoring, expert personnel, large investments, and are part of a technological lock-in where corporate profits prevail over local autonomy. System stability or return to stability is easier in smaller systems: they are easier to inspect, maintain, repair, and renovate. In the United States, the majority of water systems are small-scale, decentralized systems, often run by communities ${ }^{[76]}$ such as those in many rural areas of the world.

\section{Energy Technologies}

An energy transition is underway since global petroleum reserves will probably not outlast the $21^{\text {st }}$ century under current technologies and demand. The transition is assuming a nonrenewable form (nuclear energy, coal, fracked natural gas, shale oil, tar sands), poised to augment climate change and xenobiotic emissions. The renewable form (solar, geothermal, and wind energy mostly ${ }^{[77]}$ ) has much smaller xenobiotic emissions and relatively straightforward solutions. Biofuels, though renewable, are combustion technologies with vast greenhouse gas and xenobiotic emissions, in addition to massive use of irrigation, pesticides, and fertilizers. Similar to biofuels, the land grab for hydroelectric dams destroys wilderness and crop areas and emits methane, a greenhouse gas more potent than carbon dioxide.

Instead of being released to the atmosphere, methane can be used as fuel: methane is the lightest hydrocarbon and upon combustion releases the least carbon. Its Gibbs 
energy (chemical energy content) makes it portable. It is a natural product of microbial anaerobic biomass degradation, such as in wetlands and deep sea. Manure, food residues, and domestic wastewater are good feeds for biomethane production and outputs are fertilizer and water. ${ }^{[78]}$ Carbon dioxide produced in the process can be used in plant $\mathrm{CO}_{2}$ fertilization and has many uses in green chemistry.

So far, there are few portable energy sources able to sustainably replace gasoline; they include biomethane, electricity, hydrogen, and human/animal power. There is, however, a need to diminish electricity and hydrogen use, which augment the entropy of an energy system, meaning that energy is lost during their generation. Hybridization among portable energy sources is warranted, in particular to improve human- and animal-powered machines. In nonmobile applications, like space and water heating in households, much less energy and especially combustibles are needed when bioclimatic design, concentrated solar, and wind energies are used.

\section{Food Technologies}

Current intensive food technologies make excessive use of water, combustion, and xenobiotics to augment agricultural yield. The deleterious effects of pesticides were shown earlier. Phosphate fertilizers release radionuclides that are nonrenewable, and $85 \%$ of the world's reserves are located in just one country. ${ }^{[79]}$ As to tillage, it has led to erosion in turn requiring artificial fertilizers. Irrigation is associated with energy-intensive pumping, use of ill-treated wastewaters and soil salinization.

Running counter to intensive agriculture, resourceconserving practices have already augmented crop yields by $79 \%$ in 57 poor countries using integrated pest management based on more diverse and resilient ecosystems in agropastoral, silvopastoral, agroforestry, or crop-livestock landscapes. Livestock wastes are recirculated to restore nutrients and soil organic matter. These practices enhance water efficiency, soil fertility, and have been shown to reverse soil erosion. ${ }^{[8]}$

In addition, ecological intensification posits maximum use of local communities of organisms to regulate ecosystem-wide nutrient flow, plant growth, pathogens, and herbivores, and also to form soil and contribute to yield. ${ }^{[81]}$ Complex ecosystems (diverse in species and landscapes) and biological control (the use of insectivores, pheromones, and repellents to manage insects and nematodes) replace pesticides and monoculture. Instead of herbicides and tillage, it is possible to inhibit weed growth through mulching and enough crop leaf density to cover soil and weeds from the sun, which also reduces evapotranspiration.

As to genetic improvement, caution is warranted since higher yielding cultivars often require yet higher fertilizer inputs in order to achieve their potential. ${ }^{[79]}$

\section{Integration}

Xenobiotics mostly originate from more than one WEF sector (Fig. 2B) because WEF technologies are intertwined: water technologies are energy dependent, while staple and biofuel crops use large amounts of water and energy. This is the reason why a few independent improvements are likely to fail at remediating the momentous consequences of current WEF technologies: integration of solutions is pivotal. Integration differs from, say, mixing pig husbandry and rice cultivation, which augment the incidence of Japanese encephalitis. ${ }^{[8]}$ Integration also differs from centralized systems that mix hospital, domestic, and industrial wastewaters, ultimately used in irrigation.

The world now is globalized and urbanized so that food travels long distances. Huge amounts of solid and liquid waste egress from cities. Instead, urban landscapes should integrate agricultural uses. Mixed land uses make for complex landscapes that wild vectors of pathogens can find challenging to cross. Already pioneering cities are replacing storm sewage by a network of blue and green corridors that conveys, retains, filters, and recharges water. ${ }^{[82]}$ Roofs are increasingly used for horticulture or rainwater collection, but these functions need to be integrated. Products of urban-waste recycling must flow to rural areas: struvite (magnesium ammonium phosphate) from human waste, urine which is high in phosphorus, (an)aerobic compost, food waste, and wastewater sludge vermicompost, as well as, potentially, phosphate recovered from landfill sites. ${ }^{[79,83]}$ Overall, proximity and integration between rural and urban areas can save transportation energy. Mutual benefits emerge from integrated technologies following the model of anaerobic digestion of agricultural and human waste, which returns nutrients to agriculture and biomethane to the energy sector.

At a smaller scale, agricultural landscaping should take advantage of local water and soil. Aquaponics is exemplary: similar to some Asian traditions, it is a synergetic hybridization of horticulture and aquaculture: fish benefit from vegetal matter and crops from fish feces. Aquaponics could reduce the large impact of aquaculture feed on ocean fisheries and diversify the source of proteins in human diet. Sustainable agricultural science must follow the aquaponics model and merge with globally important agricultural heritage systems that combine local resources and climate advantages. ${ }^{[84]}$

\section{DISCUSSION}

This entry is about the expanding human exposome, the increasing number of pathogens and xenobiotics. Key issues in preventing and reverting the expansion are discussed below.

Failures of xenobiotic regulations have to be corrected. Xenobiotic regulations have been enacted following 
catastrophic events more than chronic exposure; for instance, the US Emergency Planning and Community Right-to-Know Act of 1986 was adopted after the 1984 Bhopal catastrophe. Delayed regulation allows for lengthier exposure to interacting toxicants, which even at low dose can be more lethal, ${ }^{[25]}$ especially when xenobiotics are persistent, bioaccumulate, or biomagnify. Only a fraction of the potentially toxic xenobiotics is regulated. Even the notoriously toxic dioxins lack specific regulation and whatever limits exist are umbrella regulations. ${ }^{[85]}$ International agreements on pollutants seem to have failed over the last years because they have fragmented xenobiotic issues. ${ }^{[86]}$ Also worrying are FAO-WHO recommendations endorsing hazardous metals as food additives. ${ }^{[87]}$

Relevant to improving regulations is the concurrence of pathogens or xenobiotics in the same bodily sites of action, as synergies are likely to occur and damages be potentiated. While regulations set maxima relative to one xenobiotic at a time, xenobiotic mixtures below the regulatory maxima can be deleterious.

While regulations have slowed down toxic releases, they seem to have barely reduced the expansion of our exposome. Fast viral and bacterial adaptations and mutations and new xenobiotics far outpace our rate of biological evolution. It seems that only the fast pace of sustainable technological innovation can compete with the expansion of our exposome. Prevention through adoption of available sustainable WEF technologies would be much faster and less expensive than developing medical cures. Technology improvements cannot, however, disregard the need to reduce consumption worldwide: in particular, there is more food produced now than needed to feed the world. ${ }^{[88]}$ Practical measures include: controlling overproduction, improving global food distribution, reducing the production of macronutrients (carbohydrates, fat, and proteins), augmenting the production of nutrient-dense food (high in minerals and vitamins but relatively low in calories ${ }^{[89]}$ ), producing and delivering through diet natural antivirals and antioxidants that are able to palliate parasitic diseases, viral infections, and various cancer damages. ${ }^{[90]}$

\section{CONCLUSIONS}

This entry contributed to show that emerging pathogens and current and past persistent xenobiotic emissions are more than our bodily systems should be exposed to. The entry was based almost exclusively on mechanistic studies in humans, and excluded studies on animals. Mechanistic studies deal with molecular and biochemical causes; they are devoid of the assumptions underlying statistical evidence.

Regulation cannot compensate for technology failures. But there are enough scientific information and technology alternatives to opt out critical technologies and their health consequences. Current water, energy, and food supply (the
WEF nexus) is undergirded by a very small set of technologies: combustion and biocides - pesticides and water disinfection compounds - responsible for a disproportionate number of diseases, in particular cancer-related ones. WEF technologies emit nearly all the main pollutant classes, which reach all environmental compartments, use all entryways into, and affect all systems in the human body.

Changes need not be wholesale at first: an initial focus on WEF technologies, crucial for human survival, would largely ameliorate the combined exposition to pathogens and xenobiotics. Solving for just one group of pathogens or xenobiotics would only marginally improve our technobiological system. The limited number of technological changes proposed here are sustainable independently from each other; when integrated they can prevent many ailments entrained by current WEF technologies.

Four principles can steer the transition of WEF technologies:

1. Cater to basic needs. Halt consumerism and replace consumptive uses of resources since no technology can provide WEF services beyond the possibilities of atmosphere, hydrosphere, and land

2. Prevent harm to the interdependent human and ecosystem health

3. Circulate nutrients not waste products

4. Mimic nature. Technological systems must diversify to allow for resilience and evolution. Their complexity must be adapted to local conditions

Sooner rather than later, technology changes are warranted as WEF biological effects seem to affect genetic integrity, human reproduction, and child development, all of which entail anthropogenic evolutionary pressure on current and future generations of the species.

\section{ACKNOWLEDGMENT}

We owe a debt of gratitude to Carolina Islas-Espinoza, MD for her valuable insights.

\section{REFERENCES}

1. Finch, C.E. Evolution of the human lifespan, past, present, and future: Phases in the evolution of human life expectancy in relation to the inflammatory load. Proc. Am. Philos. Soc. 2012, 156, 9-44.

2. Roth, G.; Dicke, U. Evolution of the brain and intelligence. TRENDS Cogn. Sci. 2005, 9, 250-257.

3. Ferriman, A. BMJ readers choose sanitation as greatest medical advance since 1840. BMJ 2007, 334, 111.

4. McMichael, A.J.; Woodruff, R.E.; Hales, S. Climate change and human health: Present and future risks. Lancet 2006 , 367, 859-869.

5. McMichael, A.J.; Powles, J.W.; Butler, C.D.; Uauy, R. Food, livestock production, energy, climate change, and 
health. Lancet 2007, 370, 1253-1263. doi:10.1016/S01406736(07)61256-2.

6. Morse, S. Factors and determinants of disease emergence. Rev. Sci. Tech. Off. Int. Epiz. 2004, 23, 443-451.

7. Wild, C.P.; Scalbert, A.; Herceg, Z. Measuring the exposome: A powerful basis for evaluating environmental exposures and cancer risk. Environ. Mol. Mutagen. 2013, 54, 480-499.

8. Tyler, K.L. Emerging viral infections of the central nervous system: Part 1. Arch. Neurol. 2009, 66, 939-948.

9. Czene, K.; Lichtenstein, P.; Hemminki, K. Environmental and heritable causes of cancer among 9.6 million individuals in the Swedish family-cancer database. Int. J. Cancer 2002, 99, 260-266.

10. IARC. Press Release No. 231. In Most Types of Cancer Not Due to 'Bad Luck'. IARC Responds to Scientific Article Claiming That Environmental and Lifestyle Factors Account for Less Than One Third of Cancers. International Agency for Research on Cancer: Lyon; 2015.

11. Shinde, V.; Bridges, C.B.; Uyeki, T.U.; Xu, B.; Balish, A.; Xu, X.; Lindstrom, S.; Gubareva, L.V.; Deyde, V.; Garten, R.J.; Harris, M.; Gerber, S.; Vagoski, S.; Smith, F.; Pascoe, N.; Martin, K.; Dufficy, D.; Ritger, K.; Conover, C.; Quinlisk, P.; Klimov, A.; Bresee, J.S.; Finelli, L. Triple-reassortant swine influenza A (H1) in humans in the United States, 2005-2009. N. Engl. J. Med. 2009, 361, 1-10.

12. Song, M.S.; Lee, J.H.; Pascua, P.N.Q.; Baek, Y.H.; Kwon, H.I.; Park, K.J.; Choi, H.W.; Shin, Y.K.; Song, J.Y.; Kim, C.J.; Choi, Y.K. Evidence of human-to-swine transmission of the pandemic (H1N1) 2009 influenza virus in South Korea. J. Clin. Microbiol. 2010, 48, 3204-3211.

13. Schwedt, G. The Essential Guide to Environmental Chemistry; John Wiley \& Sons: Chichester, 2001.

14. Hayward, K.; Fuerhacker, M. The challenge of emerging contaminants: Setting the course for a future of in vitro testing. Water 2012, 21, 38-39.

15. EPA. Toxics Release Inventory (TRI) Program. TRIChemical Hazard Information Profiles v.2.07. US Environmental Protection Agency, 2013. Available at http://www. epa.gov/tri/tri-chip/index.html (accessed August 2014).

16. U.S. National Library of Medicine. TOXNET. National Institutes of Health, 2014. Available at http://toxnet.nlm.nih.gov/ cgi-bin/sis/search2/ (accessed August 2014).

17. Diseases Database Ver 2.0. Medical Lists and Links, 2015, http://www.diseasesdatabase.com (accessed October 2014).

18. WHO. International Classification of Diseases. Vol. I, Chapter 1. World Health Organization, 2013. Available at http://www.cdc.gov/nchs/data/dvs/2e_volume1_2013.pdf (accessed October 2014).

19. Hirner, A.; Emons, H. Organic metals and metalloid species in the environment; Springer: Berlin, 2004.

20. Lu, F.C.; Kacew, S. Lu's Basic Toxicology; Informa Healthcare: New York, 2009.

21. IARC-WHO. Some non-heterocyclic polycyclic aromatic hydrocarbons and some related exposure. IARC Monographs Eval. Carcinogen. Risk Chem. Humans 2010, 92, $1-868$.

22. Talapatra, A.; Srivastava, A. Ambient air non-methane volatile organic compound (NMVOC) study initiatives in India -A review. J. Environ. Prot. 2011, 2, 21-36.
23. Anenberg, S.C.; West, J.J.; Fiore, A.M.; Jaffe, D.A.; Prather, M.J.; Bergmann, D.; Cuvelier, K.; Dentener, F.J.; Duncan, B.N.; Gauss, M.; Hess, P.; Jonson, J.E.; Lupu, A.; Mackenzie, I.A.; Marmer, E.; Park, R.J.; Sanderson, M.G.; Schultz, M.; Shindell, D.T.; Szopa, S.; Garcia Vivanco, M.; Wild, O.; Zeng, G. Intercontinental impacts of ozone pollution on human mortality. Environ. Sci. Technol. 2009, 43, 6482-6487.

24. Grimm, F.A.; Hu, D.; Kania-Korwel, I.; Lehmler, H.J.; Ludewig, G.; Hornbuckle, K.C.; Duffel, M.W.; Bergman, A.; Robertson, L.W. Metabolism and metabolites of polychlorinated biphenyls (PCBs). Crit. Rev. Toxicol. 2015, 45, 245-272.

25. Dutta, S.K.; Mitra, P.S.; Ghosh, S.; Zang, S.; Sonneborn, D.; Hertz-Picciotto, I.; Trnovec, T.; Palkovicova, L.; Sovcikova, E.; Ghimbocschi, S.; Hoffman, E.P. Differential gene expression and a functional analysis of PCB-exposed children: Understanding disease and disorder development. Env. Int. 2012, 40, 143-154.

26. Richardson, S.D.; Plewa, M.J.; Wagner, E.D.; Schoeny, R.; DeMarini, D.M. Occurrence, genotoxicity, and carcinogenicity of regulated and emerging disinfection by-products in drinking water: A review and roadmap for research. Rev. Mutat. Res. 2007, 636, 178-242.

27. Samal, A.; Honovar, J.; White, C.R.; Patel, R.P. Potential for chlorine gas-induced injury in the extrapulmonary vasculature. Proc. Am. Thorac. Soc. 2010, 7, 290-293.

28. Vajner, J.E.I.; Lung, D. Case files of the University of California San Francisco medical toxicology fellowship: Acute chlorine gas inhalation and the utility of nebulized sodium bicarbonate. J. Med. Toxicol. 2013, 9, 259-265.

29. Pfeifer, G.D.; Besaratinia, A. UV wavelength-dependent DNA damage and human non-melanoma and melanoma skin cancer. Photochem. Photobiol. Sci. 2012, 11, 90-97.

30. Righi, E.; Bechtold, P.; Tortorici, D.; Lauriola, P.; Calzolari, E.; Astolfi, G.; Nieuwenhuijsen, M.J.; Fantuzzi, G.; Aggazzotti, G. Trihalomethanes, chlorite, chlorate in drinking water and risk of congenital anomalies: A populationbased case-control study in Northern Italy. Environ. Res. 2012, 116, 66-73.

31. Mishra, B.K.; Gupta, S.K.; Sinha, A. Human health risk analysis from disinfection by-products (DBPs) in drinking and bathing water of some Indian cities. J. Environ. Heal. Sci. Eng. 2014, 12, 1-10.

32. EEA. Health Effects of Exposure to Ozone. Tropospheric Ozone in EU-The Consolidated Report. Topic report No.8/1998. European Environmental Agency, 1998. Available at http://www.eea.europa.eu/publications/TOP08-98/ page010.html (accessed September 2014).

33. Viñas, R.; Jeng, Y.; Watson, C.S. Non-genomic effects of xenoestrogen mixtures. Int. J. Env. Res. Public. Heal. 2012, 9, 2694-2714.

34. De Castro, V.L.S.S.; Poli, P. Pollution: Genotoxicity of agrotoxic compounds. Encycl. Environ. Manag. 2013, 3, $2123-2135$.

35. Ganmaa, D.; Sato, A. The possible role of female sex hormones in milk from pregnant cows in the development of breast, ovarian and corpus uteri cancers. Med. Hypotheses. 2005, 65, 1028-1037. 
36. Qin, L.-Q.; Wang, P.-Y.; Kaneko, T.; Hoshi, K.; Sato, A. Estrogen: One of the risk factors in milk for prostate cancer. Med. Hypotheses. 2004, 62, 133-142.

37. Swedenborg, E.; Rüegg, J.; Mäkelä, S.; Pongratz, I. Endocrine disruptive chemicals: Mechanisms of action and involvement in metabolic disorders. J. Mol. Endocrinol. 2009, 43, 1-10.

38. Loh, Y.H.; Jakszyn, P.; Luben, R.N.; Mulligan, A.A.; Mitrou, P.N.; Khaw, K.-T. N-nitroso compounds and cancer incidence: The European prospective investigation into cancer and nutrition (EPIC)-Norfolk Study. Am. J. Clin. Nutr. 2011, 93, 1053-1061.

39. Bryan, N.S.; Van Grinsven, H. The role of nitrate in human health. In Advances in Agronomy; Donald, S., Ed.; Academic Press: San Diego, 2013; 153-182.

40. Takahama, U.; Hirota, S. Effects of the food additive sulfite on nitrite-dependent nitric oxide production under conditions simulating the mixture of saliva and gastric juice. Agric. Food Chem. 2012, 60, 1102-1112.

41. Ban, G.-Y.; Kim, M.-A.; Yoo, H.-S.; Ye, Y.-M.; Park, H.-S. Two major phenotypes of sulfite hypersensitivity: Asthma and urticaria. Yonsei Med. J. 2014, 55, 542-544.

42. Paredes, D.; Kuschk, P.; Mbwette, T.S.A.; Stange, F.; Müller, R.A.; Köser, H. New aspects of microbial nitrogen transformations in the context of wastewater treatment-A review. Eng. Life Sci. 2007, 7, 13-25.

43. Campbell, K. Radionuclides in surface water and groundwater. In Handbook of Water Purity and Quality; Ahuja, S., Ed.; Academic Press: New York, 2009; 213-236.

44. Brenner, D.J.; Doll, R.; Goodhead, D.T.; Hall, E.J.; Land, C.E.; Little, J.B.; Lubin, J.H.; Preston, D.L.; Preston, R.J.; Puskin, J.S.; Ron, E.; Sachs, R.K.; Samet, J.M.; Setlow, R.B.; Zaider, M. Cancer risks attributable to low doses of ionizing radiation: Assessing what we really know. PNAS 2003, 100, 13761-13766.

45. Chauhan, P.; Chauhan, R.; Gupta, M. Estimation of naturally occurring radionuclides in fertilizers using gamma spectrometry and elemental analysis by XRF and XRD techniques. Microchem. J. 2013, 106, 73-78.

46. Pandit, G.; Sahu, S.; Puranik, V. Natural radionuclides from coal fired thermal power plants - Estimation of atmospheric release and inhalation risk. Radioprotection 2011, 46, S173-S179.

47. Damgaard, I.N.; Skakkebæk, N.E.; Toppari, J.; Virtanen, H.E.; Shen, H.; Schramm, K.-W.; Petersen, J.H.; Jensen, T.K.; Main, K.M. The Nordic Cryptorchidism Study Group. Persistent pesticides in human breast milk and cryptorchidism. Environ. Health Perspect. 2006, 114, 1133-1138.

48. Band, P.R.; Abanto, Z.; Bert, J.; Lang, B.; Fang, R.; Gallagher, R.P.; Le, N.D. Prostate cancer risk and exposure to pesticides in British Columbia farmers. Prostate 2011, 71, 168-183.

49. Chen, C.S.; Hseu, Y.C.; Liang, S.H.; Kuo, J.-Y.; Chen, S.C. Assessment of genotoxicity of methyl-tert-butyl ether, benzene, toluene, ethylbenzene, and xylene to human lymphocytes using comet assay. J. Hazard. Mater. 2008, 153, 351-356.

50. Arlt, V. M. 3-Nitrobenzanthrone, a potential human cancer hazard in diesel exhaust and urban air pollution: A review of the evidence. Mutagenesis 2005, 20, 399-410.
51. WHO. Acrylamide in Drinking-Water. Background Document for Development of WHO Guidelines for DrinkingWater Quality; WHO/SDE/WSH/03.04/71/Rev/1; World Health Organization: Geneva, 2011.

52. Wang, H.-T.; Hu, Y.; Tong, D.; Huang, J.; Gu, L.; Wu, X.-R.; Chung, F.-L.; Li, G.-M.; Tang, M.-S. Effect of carcinogenic acrolein on DNA repair and mutagenic susceptibility. J. Biol. Chem. 2012, 287, 12379-12386.

53. EPA. Acrolein. Technology Transfer Network-Air Toxics Web Site. 107-02-8. US Environmental Protection Agency, 2009. Available at http://www.epa.gov/ttnatw01/hlthef/acro lein.html (accessed October 2014).

54. WHO. Tackling the Global Clean Air Challenge. World Health Organization, 2011. Available at http://www.who. int/mediacentre/news/releases/2011/air_pollution_20110 926/en/ (accessed September 2014).

55. WHO. Air Quality and Health. Fact Sheet No. 313. World Health Organization, 2011. Available at http:/www.who.int/ mediacentre/factsheets/fs313/en/ (accessed August 2014).

56. UNEP/WHO. State of the Science of Endocrine Disrupting Chemicals 2012. United Nations Environment Program/ World Health Organization, 2013. Available at http://unep. org/pdf/9789241505031_eng.pdf (accessed August 2014).

57. Farmer, P.B.; Singh, R.; Kaur, B.; Sram, R.J.; Binkova, B.; Kalina, I.; Popov, T.A.; Garte, S.; Taioli, E.; Gabelova, A.; Cebulska-Wasilewska, A. Molecular epidemiology studies of carcinogenic environmental pollutants. Effects of polycyclic aromatic hydrocarbons (PAHs) in environmental pollution on exogenous and oxidative DNA damage. Mutat. Res. Mutat. 2003, 544, 397-402.

58. Chao, H.R.; Wang, S.L.; Lin, T.C.; Chung, X.H. Levels of organochlorine pesticides in human milk from central Taiwan. Chemosphere 2006, 62, 1774-1785.

59. Buck Louis, G.M.; Sundaram, R. Exposome: Time for transformative research. Stat. Med. 2012, 31, 1-8.

60. Singer, M. Pathogen-pathogen interaction. A syndemic model of complex biosocial processes in disease. Virulence 2010, 1, 10-18.

61. Giovannucci, E.; Pollak, M.; Liu, Y.; Platz, E.A.; Majeed, N.; Rimm, E.B.; Willett, W.C. Nutritional predictors of insulinlike growth factor I and their relationships to cancer in men. Cancer, Epidemiol. Biomarkers Prev. 2003, 12, 84-89.

62. Ganmaa, D.; Cui, X.; Feskanich, D.; Hankinson, S.E.; Willett, W.C. Milk, dairy intake and risk of endometrial cancer: A 26-year follow-up. Int. J. Cancer. 2012, 130, 2664-2671.

63. Vinson, F.; Merhi, M.; Baldi, I.; Raynal, H.; Gamet-Payrastre, L. Exposure to pesticides and risk of childhood cancer: A meta-analysis of recent epidemiological studies. Occup. Environ. Med. 2011, 68, 694-702.

64. Blair, A.; Ritz, B.; Wesseling, C.; Freeman, L.B. Pesticides and human health. Occup. Environ. Med. 2015, 72, 81-82. doi:10.1136/oemed-2014-102454.

65. Singer, M. Development, coinfection, and the syndemics of pregnancy in Sub-Saharan Africa. Infect. Dis. Poverty 2013, $2,1-10$.

66. Kramer, S.; Hikel, S.M.; Adams, K.; Hinds, D.; Moon, K. Current status of the epidemiologic evidence linking polychlorinated biphenyls and non-Hodgkin lymphoma, and the role of immune dysregulation. Env. Heal. Perspect. 2012, 120, 1067-1075. 
67. Haverkos, H.W. Viruses, chemicals and co-carcinogenesis. Oncogene 2004, 23, 6492-6499.

68. Goines, P.E.; Ashwood, P. Cytokine dysregulation in autism spectrum disorders (ASD): Possible role of the environment. Neurotoxicol. Teratol. 2013, 36, 67-81.

69. Ewing, G.E. What is regressive autism and why does it occur? Is it the consequence of multi-systemic dysfunction affecting the elimination of heavy metals and the ability to regulate neural temperature? N. Am. J. Med. Sci. 2009, 1, $28-47$.

70. Dubovický, M. Neurobehavioral manifestations of developmental impairment of the brain. Interdisc. Toxicol 2010, 3, $59-67$.

71. Sekirov, I.; Russell, S.L.; Antunes, L.C.M.; Finlay, B.B. Gut microbiota in health and disease. Physiol. Rev. 2010, 90, 859-904.

72. Zhou, S.S.; Zhou, Y.M.; Li, D.; Ma, Q. Early infant exposure to excess multivitamin: A risk factor for autism? Autism Res. Treat. 2013, 2013, 1-8.

73. Islas-Espinoza, M.; Reid, B.J.; Wexler, M.; Bond, P.L. Soil bacterial consortia and previous exposure enhance the biodegradation of sulfonamides from pig manure. Microb. Ecol. 2012, 64, 140-151.

74. Islas-Espinoza, M.; de las Heras, A. Water appropriate technologies. In Sustainability Science Science and Technology: An Introduction; de las Heras, A., Ed.; CRC Press: Boca Raton, 2014; 35-56.

75. WHO. Guidelines for the Safe Use of Wastewater, Excreta and Greywater; World Health Organization: Geneva, 2006.

76. Institute of Medicine. Global Environmental Health: Research Gaps and Barriers for Providing Sustainable Water, Sanitation and Hygiene Services; National Academies Press: Washington, DC, 2009.

77. Martinez-Cienfuegos, I.; Rincon-Mejia, E.A. Solar solutions. In Sustainability Science Science and Technology: An Introduction; de las Heras, A., Ed.; CRC Press: Boca Raton, 2014; 139-155.

78. Islas-Espinoza, M.; Weber, B. Bioenergy solutions. In Sustainability Science Science and Technology: An Introduction; de las Heras, A., Ed.; CRC Press: Boca Raton, 2014; 157-171.
79. Islas-Espinoza, M.; Burgess, J.; Wexler, M. Soil. In Sustainability Science Science and Technology: An Introduction; de las Heras, A., Ed.; CRC Press: Boca Raton, 2014; 57-78.

80. Latawiek, A.; Strassburg, B. Conciliating ecosystem services and human needs through improved land use. In Sustainability Science Science and Technology: An Introduction; de las Heras, A., Ed.; CRC Press: Boca Raton, 2014; 93-107.

81. Bommarco, R.; Kleijn, D.; Potts, S.G. Ecological intensification: Harnessing ecosystem services for food security. Trends Ecol. Evol. 2013, 28, 230-238.

82. De las Heras, A. Built environment. In Sustainability Science Science and Technology: An Introduction; de las Heras, A., Ed.; CRC Press: Boca Raton, 2014; 267-285.

83. Islas-Espinoza, M.; Solis-Mejia, L.; Esteller, M. Phosphorus release kinetics in a soil amended with biosolids and vermicompost. Env. Earth. Sci. 2014, 71, 1441-1451.

84. Koohafkan, P. Conservation and adaptive management of globally important agricultural heritage systems (GIAHS). Resour. Sci. 2009, 31, 4-9.

85. Hites, R.A. Dioxins: An overview and history. Environ. Sci. Technol. 2011, 45, 16-20.

86. Koloutsou-Vakakis, S.; Chinta, I. Multilateral environmental agreements for wastes and chemicals: 40 years of global negotiations. Environ. Sci. Technol. 2011, 45, 10-15.

87. FAO-WHO. Sixty-third Meeting of the Joint FAO/WHO Expert Committee on Food Addittives. United Nations Food and Agriculture Organization/World Health Organization, 2004. Available at www.who.int/pcs/iecfa/iecfa.htm (accessed July 2014).

88. Hazell, P.; Wood, S. Drivers of change in global agriculture. Phil. Trans. R. Soc. B. 2008, 363, 495-515.

89. USDA; USDHHS. Scientific Report of the 2015 Dietary Guidelines Advisory Committee; USDA-HHS: Washington, DC, 2015.

90. Weathers, P.J.; Arsenault, P.R.; Covello, P.S.; McMickle, A.; Teoh, K.H.; Reed, D.W. Artemisin production in Artemisia annua: Studies in planta and results of a novel delivery method for treating malaria and other neglected diseases. Phytochem. Rev. 2011, 10, 173-183. 